WiesŁaWa GieRAŃCZYK

Uniwersytet Mikołaja Kopernika, Torun

\title{
Rola własności intelektualnej w budowaniu innowacyjności krajów Unii Europejskiej
}

Przełom XX i XXI w. to okres, w którym nasilają się procesy rozwoju cywilizacyjnego, przejawiające się $\mathrm{w}$ przechodzeniu $\mathrm{z}$ fazy industrialnej i postindustrialnej do fazy społeczeństwa informacyjnego (Zioło 2009). Proces kształtowania się społeczeństwa informacyjnego stymulowany jest rozwojem nauki, techniki i nierozerwalnie związany z wykorzystaniem informacji, umiejętnością sprawnego korzystania ze zdobyczy techniki i posługiwania się dostępnymi nowoczesnymi technologiami. Umiejętność wykorzystania wiedzy i informacji jest podstawą budowania innowacyjności. Zasadniczym celem innowacji jest racjonalizacja wytwarzania i eksploatacji produktów oraz świadczenia usług. Wiąże się to z efektywnym użytkowaniem energii i materiałów, a także czasu pracy oraz z ochroną miejsc pracy i środowiska. Klucz do rozwoju przez innowacje stanowi człowiek i jego akceptacja dla nowości oraz jego zdolności twórcze.

Innowacyjność jest zdolnością zastosowania aktu kreatywności, nowych idei, wynalazków. Innowacyjność wyrażana jest poprzez poszukiwanie nowych kombinacji czynników wytwórczych, wnoszenie nowej wartości dodanej do konkurencyjnych produktów oraz wykorzystanie osiągnięć nauki w procesie produkcji. Nieznany wcześniej produkt przedsiębiorstwa jest wynikiem jego innowacyjności. Jeśli zostanie wdrożony w praktyce, stanie się innowacją. Innowacja jest produktem wiedzy i oznacza powstanie czegoś nowego oraz wzbogacanie wiedzy. Innowacja oznacza również wiedzę, na którą jest popyt (Barczak 2006). We współczesnym świecie innowacje są siłą napędową rozwoju gospodarczego, a nowe produkty, wzory, znaki i projekty twórcze są sprawą kluczową w podejmowaniu codziennych decyzji gospodarczych. Wiedza w nich zawarta jest najcenniejszym składnikiem wartości przedsiębiorstwa, przy czym nauka staje się coraz bardziej uprzemysłowiona - staje się przemysłem i pracuje dla przemysłu. Efektem tego zjawiska jest gwałtowne przyspieszenie procesów rozwoju przemysłowego opartego na wciąż rosnącej zależności od wiedzy i informacji. Najbardziej rentowne stały się gałęzie przemysłu bazujące na osiagnnięciach współczesnych nauk przyrodniczych i informatyki, a rozwój tych dziedzin nauki jest coraz mocniej kształtowany przez popyt przemysłu (Witek, Czernicki 2006). Tempo i zakres wdrażania innowacji warunkują konkurencyjność przedsiębiorstw na rynku.

Jednym z narzędzi zwiększania innowacyjności i konkurencyjności przedsiębiorstw jest własność intelektualna (Intellectual Property - IP). Własność intelektualna stanowi tę część wiedzy zgromadzonej przez przedsiębiorstwo i posiadanej przez jego pracowników, która jest jawna i chroniona prawem. Termin własność intelektualna stosowany jest od 1967 r., 
gdy utworzono Światową Organizację Własności Intelektualnej WIPO (World Intellectual Property Organization). Prawna ochrona dóbr niematerialnych jest jednym z warunków podejmowania i prowadzenia prac badawczo-rozwojowych, rozpowszechniania wyników tych prac, transferu technologii, inwestycji oraz współpracy w tym zakresie, zarówno na poziomie krajowym, jak i międzynarodowym. Rzeczywiste zasoby własności intelektualnej i przemysłowej uznawane są jako kluczowe i tworzą znaczącą wartość dodaną przedsiębiorstwa. Postępowe współczesne przedsiębiorstwa podejmują różnorakie działania wydobycia wszelkich możliwych wartości z nabytych praw wyłącznych do efektywnego ich wykorzystania w rozwoju przedsiębiorstwa. Przedsiębiorstwa, które poświęcają czas i środki w celu ochrony zasobów własności intelektualnej, mogą zwiększać swoją konkurencyjność na wiele sposobów. Znajomość reguł i zasad ochrony własności przemysłowej i intelektualnej pozwala na niedopuszczanie konkurentów do powielania lub dokładnego kopiowania produktów, unikanie nieekonomicznych inwestycji badawczo-rozwojowych i marketingowych, kreowanie wizerunku firmy za pomocą znaku towarowego i jakościowej strategii firmy, negocjowanie licencji, koncesjonowanie lub zawieranie innych umów w oparciu o własność intelektualną, zwiększa wartość rynkową firmy, daje możliwość zdobywania łączonego kapitału i ułatwia dostęp do finansów oraz nowych rynków (Rózga 2009).

Ponadto, przedsiębiorstwa, które prowadzą systematyczne badania z zakresu czystości patentowej, przed wystąpieniem o uzyskanie ochrony są w stanie uniknąć niepotrzebnych sporów, oszczędzając tym samym czas i finanse. Jednocześnie prawa wyłączne są podstawą komercjalizacji wynalazków, urynkowienia marki, licencjonowania know-how czy łączenia kapitałów kontraktowych.

Przedmiotami podlegającymi ochronie prawami własności intelektualnej są utwory autorskie $^{1}$ oraz przedmioty własności przemysłowej ${ }^{2}$. Z punktu widzenia gospodarczego szczególnie ważna jest własność przemysłowa. System ochrony własności przemysłowej jest systemem międzynarodowym, a jego fundamentem jest Konwencja Paryska z 1883 r., pozostająca do dziś w mocy. Zgodnie z tą konwencją, przedmiotem ochrony własności przemysłowej, obok wzorów użytkowych ${ }^{3}$, wzorów przemysłowych ${ }^{4}$, znaków towarowych, są przede wszystkim wynalazki chronione patentami. Mianem patentu określane jest prawo do wyłącznego korzystania z danego wynalazku. Systemy patentowe nie definiują pojęcia wynalazku jako takiego, każdy system krajowy podaje natomiast definicję wynalazku podlegającego opatentowaniu. Zgodnie z obowiązującą obecnie polską definicją, odpowiadającą definicji patentu europejskiego, patenty udzielane są na wynalazki, które są nowe, nadają się do przemysłowego zastosowania bez względu na dziedzinę techniki, posiadają poziom wynalazczy oraz zostały dostatecznie ujawnione w opisie zgłoszeniowym (Padeé 2005). Wynalazkami mogą być przedmioty (substancje, urządzenia, elektronika) i metody (procesy produkcji, wytwarzania, działania).

Przesłanka nowości wynalazku podlegającego opatentowaniu jest rozumiana jako nowość światowa. Rozwiązanie uważa się za nowe, jeżeli nie stanowi części stanu techniki,

1 Dobra niematerialne, stanowiące wynik twórczości artystycznej, naukowej i wynalazczej, chronione prawem autorskim (copyright), np. książki, muzyka, oprogramowanie.

2 Własność przemysłowa obejmuje prawa, które dają ich posiadaczowi wyłączny monopol na korzystanie z wynalazków technicznych, estetycznych lub charakterystycznych znaków.

3 Tzw. małe patenty, nie muszą one posiadać poziomu wynalazczego, wystarczy, że charakteryzują się użytecznością.

4 Chroniona jest postać zewnętrzna, tj. wygląd produktu (design). 
a przez stan techniki rozumie się wszystko to, co przed datą, według której oznacza się pierwszeństwo do uzyskania patentu, zostało udostępnione do wiadomości powszechnej $\mathrm{w}$ formie pisemnego lub ustnego opisu, przez stosowanie, wystawienie lub ujawnienie w inny sposób. Dla uznania wynalazku za ujawniony, a więc niespełniający kryterium nowości, nie ma znaczenia ani zasięg terytorialny, ani czasowy ujawnienia, ani kto tego dokonał. Nawet ujawnienie istotnych cech wynalazku przez jego autora lub właściciela, na przykład $\mathrm{w}$ formie artykułu w czasopiśmie naukowym lub w formie referatu na konferencji, niweczy przesłankę nowości, a tym samym pozbawia wynalazek bezpowrotnie zdolności patentowej, a zatem również możliwości uzyskania ochrony. Nowość wynalazku ustala urząd patentowy w wyniku przeprowadzonego badania. Wynalazek kwalifikujący się do ochrony patentowej musi charakteryzować się pewnym poziomem twórczej myśli, nie może być jedynie prostym wykorzystaniem znanych z różnych źródeł informacji. Wykorzystanie znanych praw i zależności w opracowaniu nowego rozwiązania technicznego nie jest samo przez się dowodem braku nieoczywistości, ale np. rozwiązanie, które polega na zastosowaniu zespołu znanych środków technicznych stosowanych wcześniej dla podobnych celów, nie spełnia kryterium poziomu wynalazczego. O poziomie wynalazczym może świadczyć również zaskakujący efekt wynalazku (Padeé 2005).

Wynalazek podlegający opatentowaniu musi nadawać się do wielokrotnego powtarzalnego stosowania, gwarantującego osiagnięcie tego samego efektu. Warunkiem stosowalności wynalazku jest także jego należyte ujawnienie oraz kompletność rozwiązania. W praktyce oznacza to, że rozwiązanie powinno zawierać wszystkie informacje niezbędne specjaliście do odtworzenia rozwiązania, nie mogą być to informacje fragmentaryczne, ujawniające tylko część środków technicznych niezbędnych do zrealizowania wynalazku. Na podstawie patentu nabywa się prawo wyłącznego korzystania z wynalazku w sposób zarobkowy lub zawodowy (Padee 2005). Odpowiednia ochrona własności intelektualnej przesądza o przewadze rynkowej i sukcesie komercyjnym przedsiębiorstw, a jednocześnie przyczynia się do powstawania kolejnych rozwiązań, decydujących o dalszym postępie naukowo-technicznym.

Wynalazki zgłoszone do ochrony, nowe znaki towarowe oraz nowe wzory przemysłowe są podstawą oceny wpływu własności intelektualnej na innowacyjność państw członkowskich UE zawartej w European Innovation Scoreboard (EIS). Wskaźniki zawarte w EIS pozwalają na konstrukcję złożonego wskaźnika innowacyjności - Summary Innovation Index (SII), umożliwiającego ocenę innowacyjności oraz efektywności innowacyjnej krajów członkowskich z uwzględnieniem nakładów i wyników ${ }^{5}$. Obok krajów unijnych EIS uwzględnia także Chorwację, Turcję, Islandię, Norwegię, Szwajcarię, Japonię, Stany Zjednoczone, Australię, Kanadę i Izrael.

Kategoria IP w SII zawierająca 5 wskaźników (tab. 1) stanowi obok kategorii opisującej zastosowanie innowacji (application - A) warstwę output SII. Warstwę Input opisują: a) czynniki napędzające innowacyjność (Innovation Drivers - ID), które obrazują warunki strukturalne rozwoju innowacyjności, b) wytwarzanie wiedzy (Knowledge Creation - KC) - ukazuje się rezultaty inwestycji w badania i rozwój, c) innowacyjność i przedsiębiorczość (Innovation and Enterprice - I\&E) - wysiłki innowacyjne na poziomie przedsiębiorstw (Gierańczyk 2009).

${ }^{5}$ Zmiany w układzie wskaźników oraz w metodologii badania opisano m.in. w pracy Markowskiej (2006). 
Tab. 1. Wskaźniki własności intelektualnej zastosowane w ocenie innowacyjności zawartej w EIS

Liczba wynalazków zgłoszonych do ochrony do EPO* na milion mieszkańców

Liczba wynalazków zgłoszonych do ochrony do USPTO** na milion mieszkańców

Liczba uzyskanych patentów w trzech urzędach patentowych***: europejskim, amery-

kańskim i japońskim - EPO, USPTO i JPO****

Liczba nowych wspólnotowych znaków towarowych na milion mieszkańców

Liczba nowych wspólnotowych wzorów przemysłowych na milion mieszkańców

* European Patent Office - Europejski Urząd Patentowy organ wykonawczy Europejskiej Organizacji Patentowej powołanej na mocy Konwencji o udzielaniu patentów europejskich; EPO ocenia zgłoszenia wniosków o patenty europejskie i je przyznaje.

** The United States Patent and Trademark Office - Urząd Patentów i Znaków Towarowych Stanów Zjednoczonych.

*** Tzw. triada patentowa (Triad Patents), wyrażający liczbę uzyskanych patentów w trzech urzędach patentowych: europejskim, amerykańskim i japońskim.

**** Japanese Patent Office - Japońskie Biuro Patentów

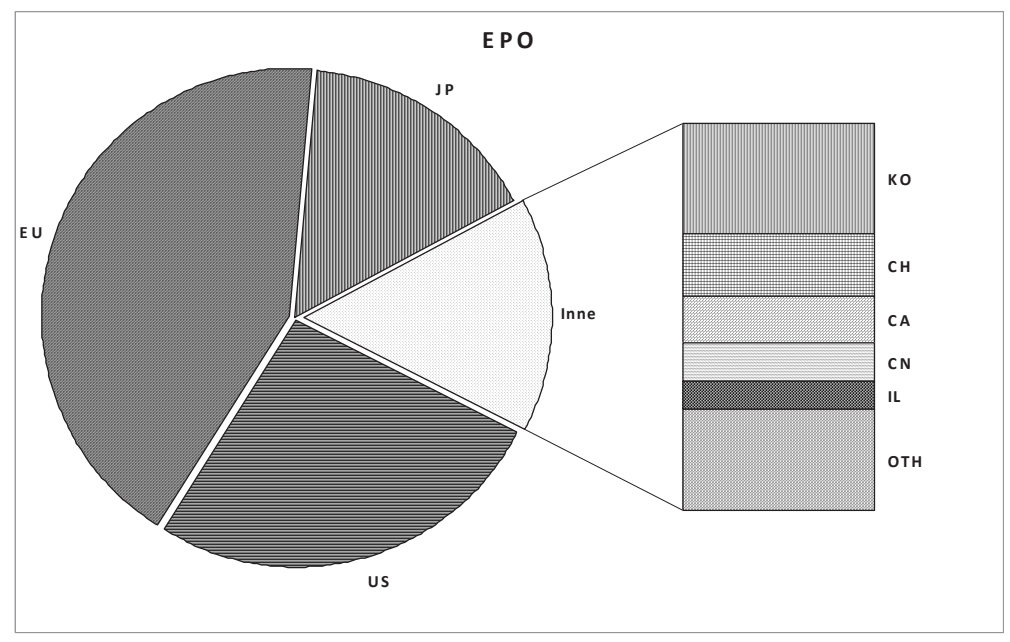

Ryc. 1. Struktura geograficzna wynalazków zgłoszonych w EPO w 2006 r.

Z przeprowadzonych badań wynika, że światowy rynek praw, które dają ich posiadaczom wyłączny monopol na korzystanie $z$ wynalazków technicznych lub estetycznych i charakterystycznych znaków, jest skoncentrowany przestrzennie. W 2006 r. ponad 90\% zgłoszonych w amerykańskich i europejskich urzędach patentowych wynalazków oraz udzielonych patentów w triadzie przypadało na UE, Japonię i USA (ryc. 1, 2, 3). Kraje UE relatywnie więcej rejestrowały wynalazków w EPO, a Stany Zjednoczone w USPTO. Udział rejestrowanych w tych urzędach wynalazków japońskich utrzymywał się na poziomie 16-20\%. W latach 1995-2006 wskaźnik koncentracji rynku wynalazków i patentów w analizowanych urzędach mierzony indeksem $\mathrm{HHI}^{6}$ był bardzo wysoki, ale wykazywał niewielką tendencję do spadku

${ }^{6}$ HHI (Herfindahl-Hirschman Index) - miara koncentracji rynku (Łyszkiewicz 2000). HHI równy jest sumie kwadratów udziałów rynkowych $(\mathrm{S})$ wszystkich podmiotów działających na rynku $(\mathrm{N})$ : 
(tab. 2). Wynikało to ze wzrostu aktywności patentowej w innych państwach, głównie azjatyckich: Chinach, Indiach, Korei Południowej Singapurze i Izraelu. W skali globalnej udział tych państw w rynku wynalazków i patentów był niewielki (ryc. 4), ale dynamika wzrostu aktywności IP bardzo duża.

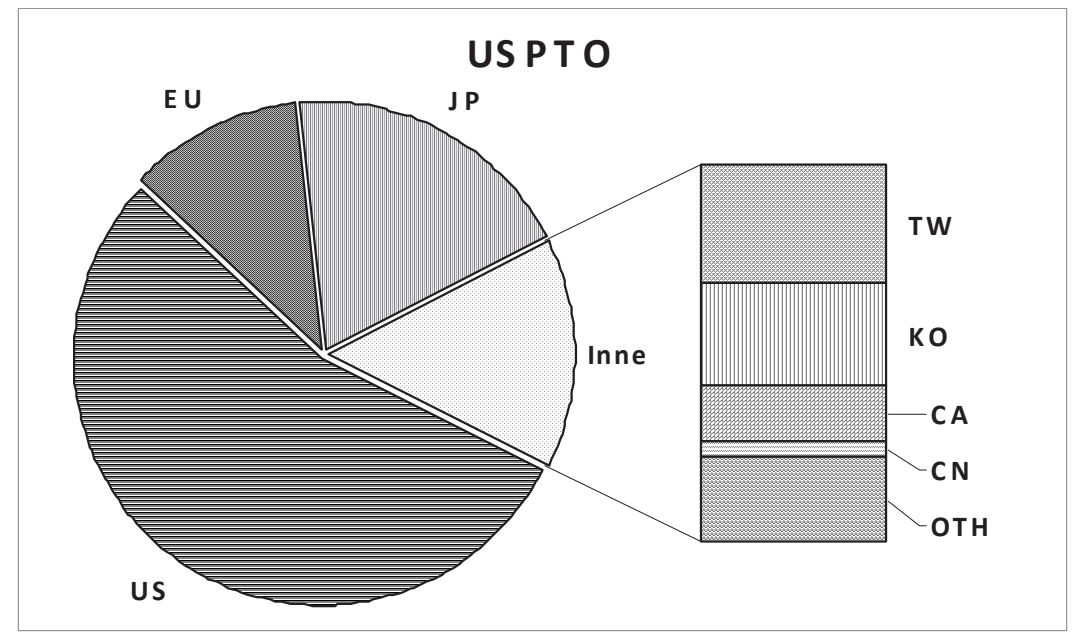

Ryc. 2. Struktura geograficzna wynalazków zgłoszonych w USPTO w 2006 r.

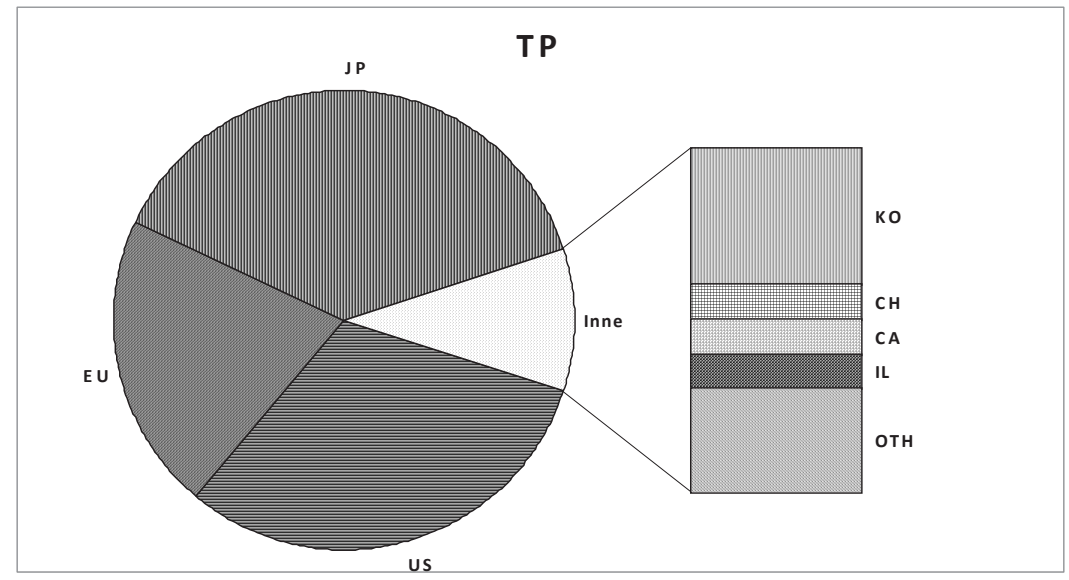

Ryc. 3. Struktura geograficzna patentów uzyskanych w trzech urzędach patentowych: europejskim, amerykańskim i japońskim - EPO, USPTO i JPO

$$
\mathrm{HHI}=\sum_{i=1}^{N} S_{i}^{2}
$$

Wskaźnik przyjmuje wartości z przedziału $(1 / N ; 1)$, przy czym im wyższa wartość wskaźnika, tym wyższa koncentracja rynku. 
Tab. 2. HHI - indeks koncentracji rynku wynalazków zgłoszonych w EPO i USPTO uraz patentów udzielonych w EPO, USPTO i JPO

\begin{tabular}{llll}
\multicolumn{1}{r}{ Urząd patent. } & 1995 & 2000 & 2006 \\
EPO & 0,323 & 0,312 & 0,275 \\
USPTO & 0,378 & 0,347 & 0,348 \\
TP & 0,294 & 0,283 & $0,285^{*}$
\end{tabular}

* 2003

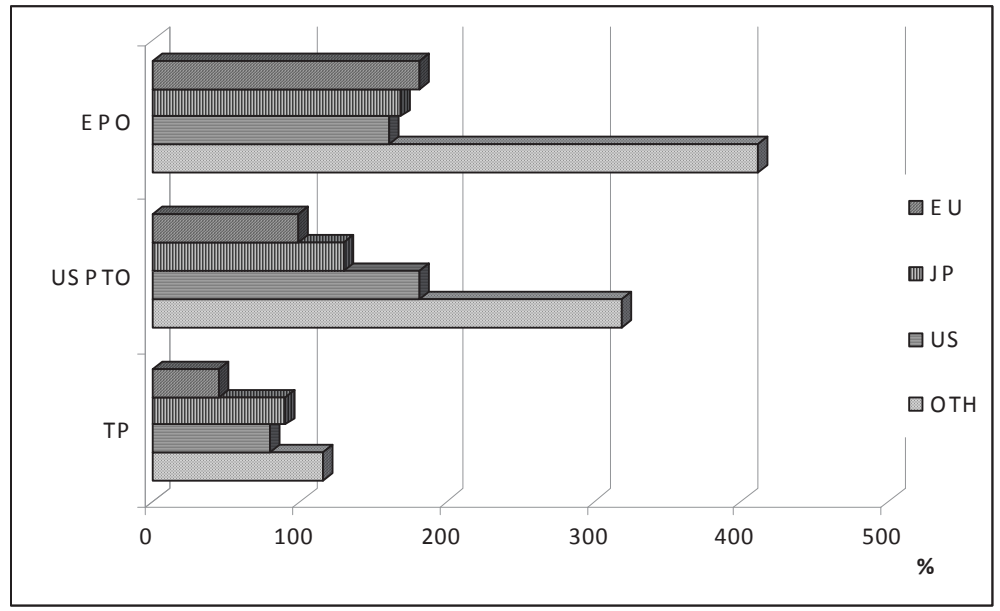

Ryc. 4. Dynamika zgłoszonych w EPO i USPTO wynalazków i udzielonych patentów w EPO, USPTO i JPO w latach 1995-2006

W latach 1995-2006 liczba zgłoszonych wynalazków, np. chińskich i indyjskich w EPO i USPTO, wzrosła ponad tysiąc razy, a uzyskanych patentów w triadzie ponad 500 razy. Jednocześnie zauważa się, że w grupie triady w badanym okresie najniższą aktywnością wynalazczą i patentową odznaczała się UE, zwłaszcza w urzędach pozaunijnych. W 2006 r. liczba zgłoszonych wynalazków w USPTO była na poziomie z 1995 r., podczas gdy liczba zgłoszonych wynalazków japońskich i amerykańskich była wyższa o odpowiednio $30 \%$ i $80 \%$. W badanym okresie systematycznie spadała liczba uzyskiwanych przez kraje triady patentów w trzech urzędach patentowych: europejskim, amerykańskim i japońskim, przy czym spadek ten w największym stopniu dotyczył krajów UE (ryc. 5).

Zaobserwowane tendencje wskazują, że o ile dystans między krajami triady pod względem aktywności patentowej w EPO zmniejsza się, chociaż w 2006 r. liczba zgłoszonych w tym urzędzie wynalazków japońskich i amerykańskich w przeliczeniu na 1 mln mieszkańców była znacznie wyższa niż w UE, to w odniesieniu do USPTO i TP ten dystans zwiększa się. W 2006 r. liczba zgłoszonych w USPTO wynalazków japońskich i amerykańskich na $1 \mathrm{mln}$ mieszkańców była ponad pięciokrotnie wyższa niż na obszarze UE. 


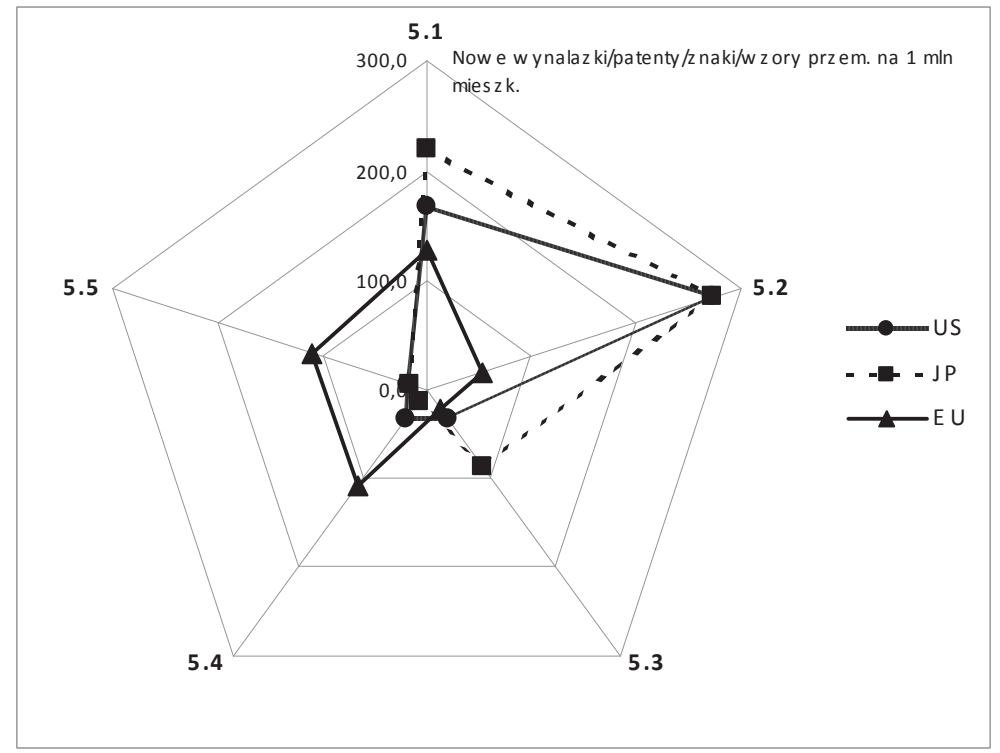

Ryc. 5. Poziom IP w UE, Japonii i Stanach Zjednoczonych w 2006 r.

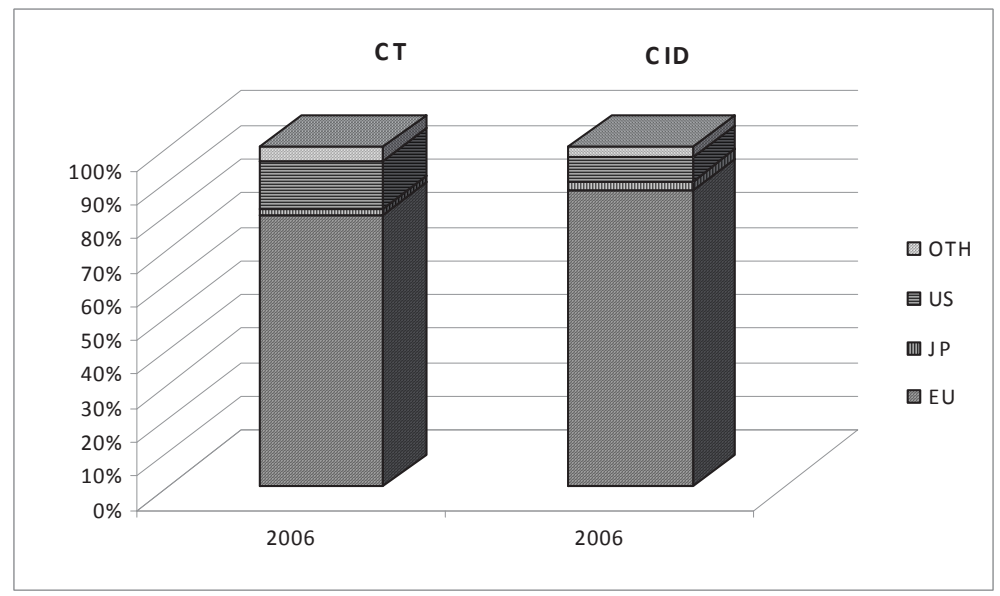

Ryc. 6. Struktura geograficzna nowych wspólnotowych znaków towarowych (CT) oraz nowych wspólnotowych wzorów przemysłowych (CID) na milion mieszkańców w 2006 r.

Nieco inaczej rozkładała się aktywność krajów triady pod względem rejestracji wspólnotowych znaków towarowych i wspólnotowych wzorów przemysłowych. Wspólnotowy znak towarowy wraz ze wspólnotowym wzorem przemysłowym są specyficznymi dla Unii Europejskiej rozwiązaniami, zrywającymi z tradycyjnie pojmowaną zasadą terytorializmu ochrony praw własności przemysłowej, ograniczającą skuteczność praw własności przemysłowej do określonego terytorium państwowego (Szczepanowska-Kozłowska 2004), stąd W większości rejestrowane wspólnotowe znaki i wzory pochodziły z krajów unijnych (ryc. 6). Są one świadectwem własności intelektualnej, które nadaje jego właścicielowi prawa 
obowiązujące na całym obszarze UE. W 2006 r. liczba zarejestrowanych na obszarze UE wspólnotowych znaków towarowych i marek handlowych z krajów UE w przeliczeniu na 1 mln mieszkańców była kilkakrotnie wyższa niż w japońskich czy amerykańskich.

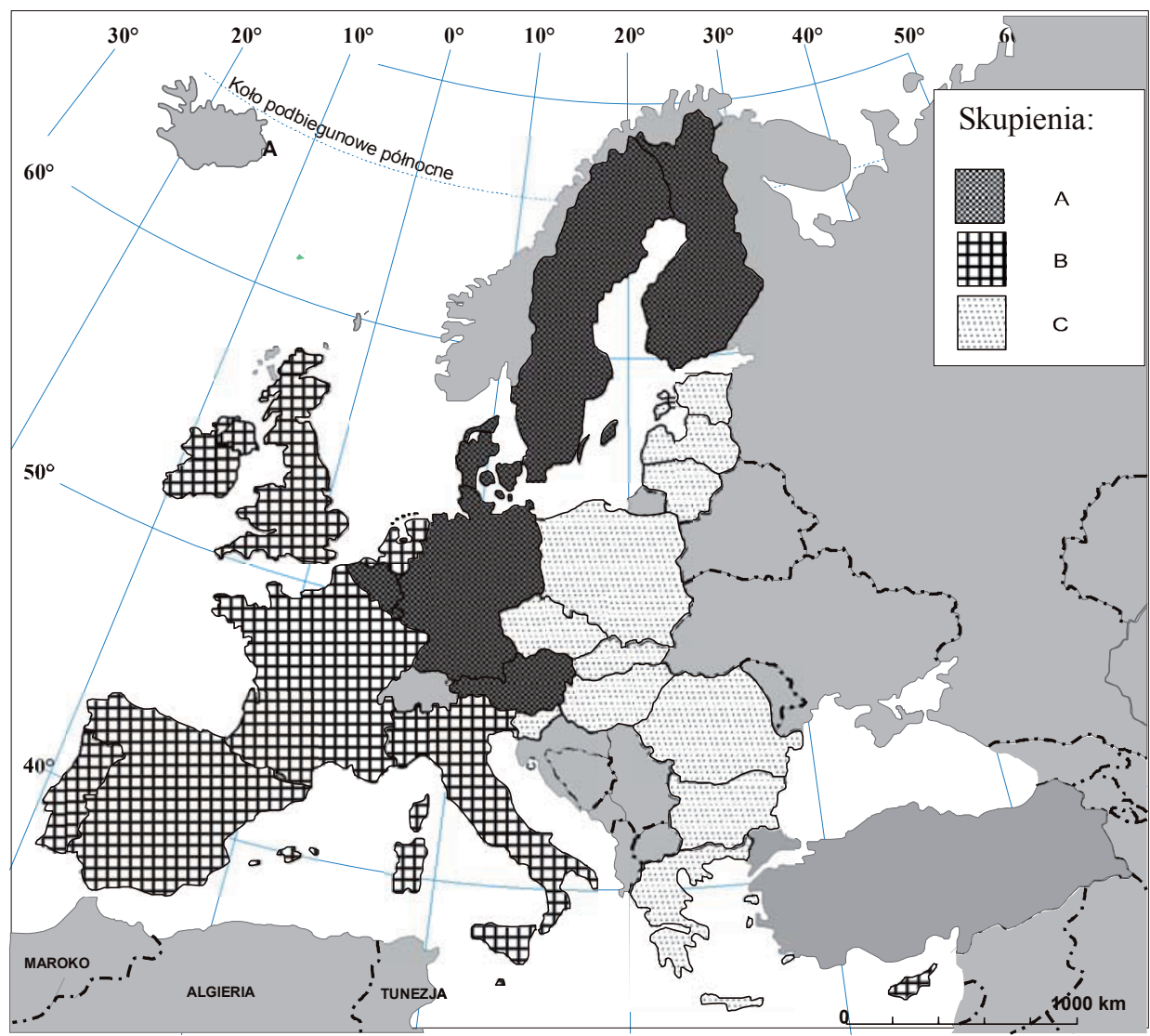

Ryc. 7. Podobieństwo państw UE pod względem zmiennych opisujących własność intelektualną w SII w 2006 r.

Analiza wskaźników obrazujących wkład własności intelektualnej w ogólny poziom innowacyjności badanych państw europejskich wykazała duże dysproporcje między krajami UE. Wynik aglomeracji państw UE pod względem zmiennych analizowanych przy ocenie IP metodą Warda pozwolił wyodrębnić 3 skupienia państw wewnętrznie podobnych, a jednocześnie różnych od pozostałych skupień (ryc. 7). Skupienie 1 tworzyły kraje skandynawskie, Niemcy, Holandia, Luksemburg i Austria. Grupa ta wykazywała we wszystkich przyjętych wskaźnikach IP ponaddwukrotnie wyższą aktywność niż średnio w UE. Zdecydowanymi liderami tej grupie jak i w całej UE pod względem zgłaszanych wynalazków były Finlandia i Niemcy. Kraje te wykazywały w 2006 r. największą w UE liczbę udzielonych patentów na $1 \mathrm{mln}$ mieszkańców. Z kolei zdecydowanym liderem pod względem zgłoszonych wspólnotowych marek handlowych był Luksemburg. W 2006 r. średnio w tym kraju na $1 \mathrm{mln}$ mieszkańców przypadały 902 znaki handlowe, podczas gdy w UE średnio 108. 


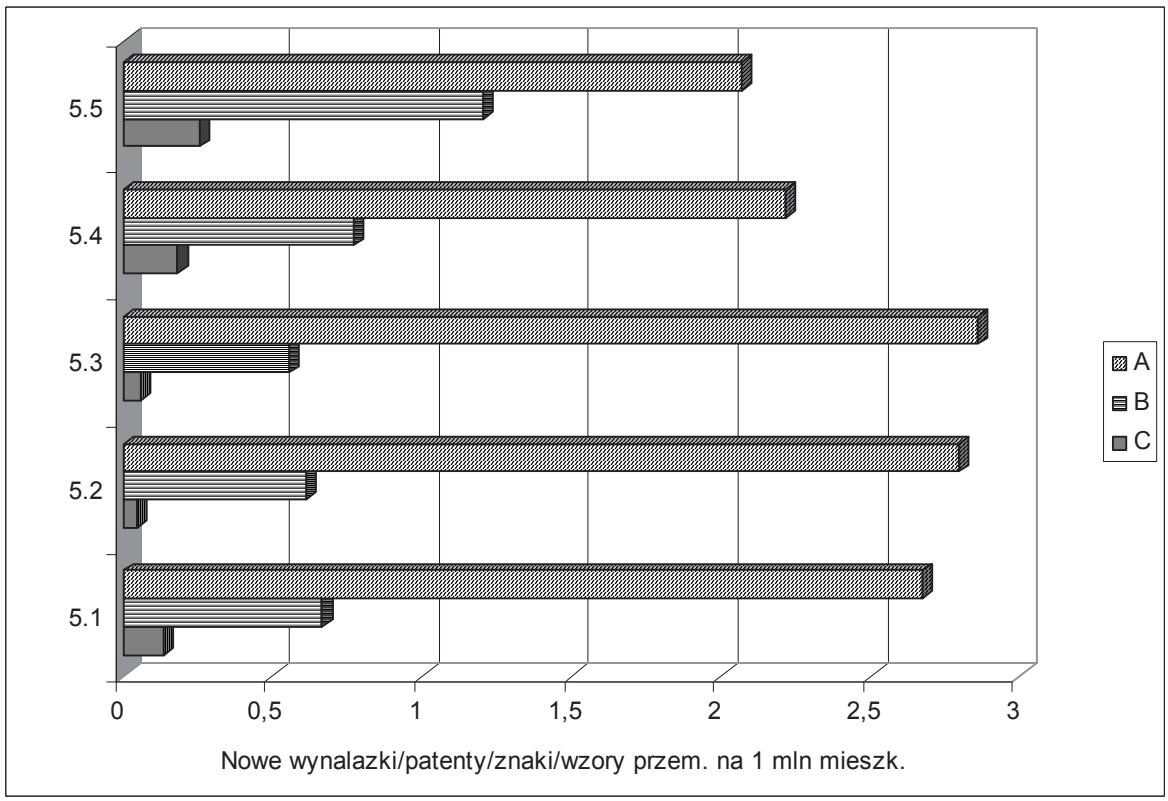

Ryc. 8. Średnie wskaźników IP dla grup państw UE wydzielonych drogą aglomeracji Warda

Grupę 2, którą tworzyły pozostałe kraje „starej” UE oraz Malta i Cypr, cechował zbliżony do średniej unijnej poziom IP pod względem wspólnotowych marek handlowych i znaków przemysłowych oraz nieco niższa niż średnio w UE aktywność wynalazcza (ryc. 8). Malta i Cypr wykazywały aktywność przede wszystkim pod względem rejestrowanych marek handlowych. W 2006 r. w tych państwach zarejestrowano ponad 120 znaków towarowych na 1 mln mieszkańców i były to wskaźniki wyższe niż w Finlandii, Włoszech, Belgii, Islandii i Portugalii.

Natomiast skupienie 3 agregowało pozostałe kraje ,nowej” UE. Pod względem wszystkich badanych zmiennych charakteryzujących IP skupienie to znacznie odbiegało od przeciętnych wskaźników dla UE. Największy dystans skupienie to wykazywało pod względem zgłaszanych wynalazków w USPTO, najmniejszy pod względem rejestrowanych wspólnotowych wzorów przemysłowych. W 2006 r. najwyższą aktywnością w tym względzie wykazywały się Czechy i Słowenia, gdzie zarejestrowano ponad 50 wzorów przemysłowych na 1 mln mieszkańców. Zdecydowanie najniższym poziomem IP w całej UE odznaczały się Rumunia i Bułgaria. W krajach tych poziom aktywności wynalazczej był prawie stukrotnie niższy niż średnio w UE.

Przeprowadzone badania wskazują, że sfera własności intelektualnej, która odrywa kluczową rolę w budowaniu innowacyjności i pozwala czerpać korzyści z twórczej kreatywności zasobów ludzkich, jest na obszarze UE silnie spolaryzowana (najsilniej spośród wszystkich warstw SII - Gierańczyk 2009), co znacząco osłabia pozycję UE na arenie międzynarodowej. Niedostateczna ochrona własności intelektualnej i niższa aktywność wynalazcza UE niż u konkurentów (zwłaszcza krajów „nowej” UE) utrudnia zdobywanie przewagi rynkowej i sukcesów komercyjnych przedsiębiorstwom, co jednocześnie ogranicza powstawanie kolejnych rozwiązań, decydujących o dalszym postępie naukowo-technicznym. Niewatpliwie 
stymulantą efektywnego wykorzystania nakładów na B\&R jest ochrona własności intelektualnej. Najważniejszym racjonalnym ekonomicznym uzasadnieniem ochrony IP jest tworzenie finansowej motywacji dla powstania, rozwoju i komercjalizacji wartościowych pomysłów (Burk, Lemley 2003). Ochrona wiedzy zawartej w produktach czy procesach ułatwia firmom czerpanie korzyści z ich zdolności innowacyjnej i twórczej, co pomaga i zachęca do utrzymywania wysokiego poziomu innowacyjności. Ochrona IP umożliwia bowiem gwarancję czasowej wyłączności na wysoką sprzedaż dzięki uzyskanemu prawnie monopolowi i stanowi zwykle zachętę do ponoszenia wyższych nakładów na B\&R. Zauważa się, że aktywność wynalazcza jest silnie skorelowana z wydatkami na B\&R, ale tworzenie innowacyjnej gospodarki zależy nie tylko od prowadzonej działalności badawczo-rozwojowej, ale również od uwarunkowań społeczno-instytucjonalnych oraz współpracy sektora $\mathrm{B} \& \mathrm{R}$ z przedsiębiorstwami. Chronione prawem wynalazki są jednym z podstawowych narzędzi gry rynkowej, dzięki nim realizowana jest współpraca pomiędzy nauką a przemysłem.

\section{Literatura}

Barczak B., 2006, Zarzqdzanie wiedza jako czynnik zwiększania potencjału innowacyjnego firmy, „Zeszyty Naukowe Akademii Ekonomicznej w Krakowie”, nr 700, s. 79

Burk D. L., Lemley M. A., 2003, Policy Levers in Patent Law, Virginia Law Review, nr 89, s. 1575, 1597.

Gierańczyk W., 2009, Innowacyjność jako główny filar społeczeństwa informacyjnego Europy, [w:] Funkcje przemystu w ksztaltowaniu społeczeństwa informacyjnego, red. Z. Zioło, T. Rachwał, Prace Komisji Geografii Przemysłu PTG, nr 13, Warszawa-Kraków, s. 82-94.

Markowska M., 2006, Statystyczny pomiar innowacyjności w krajach Unii Europejskiej, [w:] Ekonometria. Zastosowania metod ilościowych, red. nauk. J. Dziechciarz, Prace Naukowe Akademii Ekonomicznej, nr 1100, Ekonometria XVI, Wydawnictwo Akademii Ekonomicznej, Wrocław, s. 110-120.

Łyszkiewicz W., 2000, Industrial Organization. Organizacja rynku i konkurencja, Dom Wydawniczy Elipsa, Warszawa, s. 70.

Padeé G., 2005, Własność przemystowa w transferze technologii, http://innowacje.not.org.pl.

Rózga B., 2009, Korzyści ochrony własności przemystowej, Fundacja Rozwoju Przedsiębiorczości, Łódź, http://www.frp.lodz.pl/wlasnosc-przemyslowa/

Szczepanowska-Kozłowska K., 2004, Wspólnotowy znak towarowy, „Przegląd Prawa Handlowego”, $\mathrm{nr} 10$.

Witek R., Czernicki Ł., 2006, Metodyka ochrony własności intelektualnej w zakresie transferu wiedzy i innowacji z instytucji naukowo-badawczych do przedsiębiorstw, Wrocław.

Zioło Z., 2009, Rola przemystu w ksztaltowaniu spoteczeństwa informacyjnego, [w:] Funkcje przemystu w ksztaltowaniu społeczeństwa informacyjnego, red. Z. Zioło, T. Rachwał, Prace Komisji Geografii Przemysłu PTG, nr 13, Warszawa-Kraków, s. 11-20. 


\section{Role of intellectual innovation in the EU states}

The world development is characterized by blurring the division between science and economy. As a result, industrial development based on a growing dependency on knowledge and information has accelerated. In turn, due to the development of the knowledge-based economy, the importance of the so-called intellectual property laws is also on the increase. Protection of these laws not only constitutes one of the main branches of the market, but also remains a transaction object. This way cooperation between science and industry finds its realization. It enables the partners to gain dominance on the market and leads to creating new solutions which further power technological progress.

dr Wiesława Gierańczyk

Uniwersytet Mikołaja Kopernika w Toruniu

Instytut Geografii

wiesia@umk.pl 